\title{
The prevalence of hepatitis $-B$ and $C$ serological markers among patients with thalassaemia in Mosul
}

\author{
Bashar Sh. Mustafa \\ College of Pharmacy, University of Mosul, Iraq
}

\begin{abstract}
Background: Thalassaemic patients are known to have higher risk of developing hepatitis $B$ and $C$ than normal individuals. The aim of this paper is to determine the prevalence of hepatitis $B$ and $C$ among thalassaemic patients and to pinpoint its association with personal medical fators in the province of Mosul.

Methods: From August $r \ldots r$ to March $r \ldots \varepsilon, 7 r r$ patients under the age of $r$. years with thalassaemia were surveyed and screened for hepatitis HBs Ag and anti-HC Antibody (Ab) in the Thalassaemia Center in Ibn AL-Atheer Children Hospital in Mosul .

Results: $0.09 \%$ of the patients have positive HBs $\mathrm{Ag}(1.94 \%$ have combined hepatitis $\mathrm{B}$ and $\mathrm{C}$ ), $r \wedge .1 r \%$ have anti HC-Ab. The prevalence of hepatitis $B$ and $C$ was higher in patients older than 10 years.

Conclusion: Viral hepatitis is prevalent in thalassaemic patients in Mosul. Seropositivity is significantly related to age, vaccination, family history of hepatitis, history of splenectomy; number of blood transfusion per year, and severity of thalassaemia.
\end{abstract}

Keywords: Thalassaemia, HBs Ag, HCV, serologic markers-prevalence.

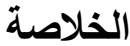

هدف الدراسة: تهدف الدراسة الى معرفة مدى انتشار مرض الكبد الفيروسي نوع B و C في مرضى الثلاسيميا

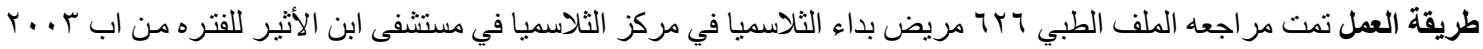

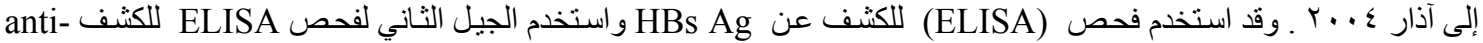

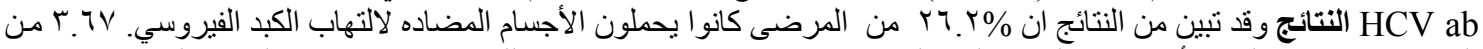

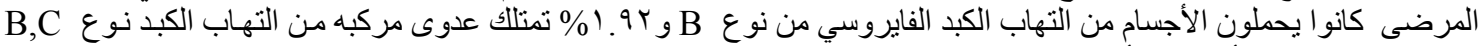

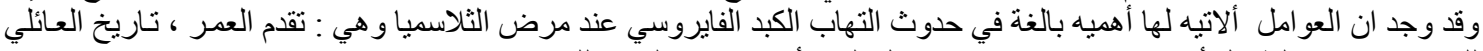

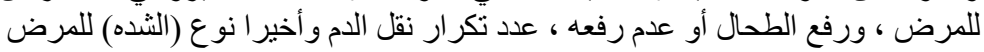
الاستتناج: ان برنامج التحصين ضد مرض التهاب الكبد الفايروسي كان فعال جدا في تقليل حدوث الالتهابات الفيروسيه .

B most serious health problems worldwide, accounting for a major number of childhood deaths per year primarily in regions of the world endemic for malaria.

Viral hepatitis continues to be a major health problem in developed and developing countries. The hepatitis B virus is globally distributed among humans. Though HBs Ag has been found in other primate, human remain the principal reservoir' $\mathrm{HBV}$ alone is estimated to have infected $\Sigma$.. million people throughout the globe, making HBV one of the most common human pathogens.

Almost all of the parentrally acquired cases of what was previously known as non-A, non-B hepatitis. ' The virus is transmitted Primarily by blood and blood product, the majority of infected individuals have either received blood transfusion prior to 199. or have used intravenous drugs. 
Little data are available on the seroprevalence of, and risk factors for hepatitis $B$ and $C$ viruses (HBV and $\mathrm{HCV}$ ) infection in thalassaemic patients in Mosul.

The aim of this paper is to determine the prevalence of hepatitis $B$ and $C$ in the thalassaemic patients under the age of $r$. in the province of Mosul.

\section{Patients and Methods}

This study was carried out in the Thalassaemic center in Ibn Al-Atheer Children Hospital in Mosul during the period from August $r \ldots r$ to March r... . The medical records of 7 r patients with thalassaemia were surveyed and analyzed. All patients screened for hepatitis HBs $\mathrm{Ag}$ and anti-HC Antibody (Ab). The following data were collected from each medical record:

1. Name, age and sex.

$r$. Residence, family history of hepatitis and past surgical history.

r. Vaccination history whether complete or incomplete.

$\varepsilon$. Frequency of blood transfusion per year (monthly or more than once per month).

- Duration of disease (Bthalassaemia) and type of thalassaemia.

7. Serological viral markers were screened second generation ELISA test for anti-HCV $\mathrm{Ab}$ and by ELISA test for HBs Ag which were done once for each patient.

The results were analyzed using the Chi-square $\left(X^{r}\right), \quad P<\cdot .0$ was considered significant.

\section{Results}

The prevalence of anti-hepatitis $\mathrm{C} \mathrm{Ab}$ and $\mathrm{HBs}$ $\mathrm{Ag}$ in thalassaemic patients are significantly high. $0.09 \%$ of the patients had positive HBs $\mathrm{Ag}$ ( $1.9 r \%$ have combined hepatitis $\mathrm{B}$ and $\mathrm{C}$ ), r^. $r \%$ have anti HC-Ab. The prevalence of hepatitis $B$ and $C$ was higher among older age group (older than 10 years) $(\mathrm{P}<\cdot . \cdots 1)$.

Seropositivity is significantly related to age, vaccination, family history of hepatitis, history of splenectomy, frequency of blood transfusion per year, and severity of thalassaemia.

The sex has no significance in the prevalence of hepatitis B and $C$ in thalassaemic child.
Vaccination against hepatitis B was crucial factor that affect the rate of prevalence of hepatitis; $11.47 \%$ of the patients were not vaccinated and only $\cdot r v \%$ of the patients vaccinated $(p<\cdot . \cdots)$ ). Thalassaemic patients with splenectomy have higher rate of hepatitis $B$ and $C$ prevalence ( 0 . $. \vee \leqslant \%$ ) in comparison with those without splenectomy (19.r\%) $(p<\cdot, \cdots)$. There was clear and evident relationship between the frequency of transfusion and prevalence of hepatitis B and $C$ with more than ir blood transfusion per year. $\leqslant r . r \%$ are hepatitis positive while only $(r \cdot . T \vee \%)$ with less than ir per year where positive.

The type (severity) of thalassaemic has strong relation to the prevalence of hepatitis $B$ and $C,(p<\cdot \ldots))$ were it was found that there is $r$ r. 9 r\%of thalassaemia major have positive hepatitis; as r. ro\% of patients with thalassaemia intermedia have positive hepatitis. With disease duration for more than $\uparrow$ years (i.e. before screening program application) $\leqslant 7.1 \%$ of them where hepatitis positive and the disease for less than 7 years (i.e. after screening program application) I . 7 r\% of them where hepatitis B positive.

The total number surveyed were ri; I 1 ( $Y ., Y . \%)$ of them were hepatitis $C$ positive, $r$ patients ( $r .7 v \%$ ) were hepatitis $B$ positive and ir patients ( $1.9 r \%$ ) had both hepatitis $B$ and $C$ as shown in the Table I. Anti-HC $\mathrm{Ab}$ were positive in $17 \leqslant$ patients (YT. Y.\%).

There is a direct relationship between the age and the seropositvity to anti-HCV $\mathrm{Ab}$ and HBs Ag. $(p<\cdot . \cdots), D F=r$ (very highly significant) were $79.07 \%$ of the hepatitis positive patients where older than 10 years patients with $(1 \cdot . \wedge \vee \%$ for hepatitis $B, 0 . \%$ for hepatitis $C$ and $\wedge .79 \%$ for co-infection with hepatitis $\mathrm{B}$ and $\mathrm{C}$ ) while only $1 \leqslant . . \leqslant \%$ of the patients younger than $T$ year. There is no significant relation between sex and the prevalence of hepatitis $B$ and $C$.

There is no relation between the residence and the prevalence of hepatitis $B$ and $\mathrm{C}$.

The interfamilial transmission of hepatitis $B$ and $C$ in thalassaemic patients was highly significant; where $r$ r. $r \vee \%$ of the patients had positive family history of hepatitis while only $1 \wedge . \wedge \uparrow \%$ had negative family history of hepatitis $(p<\cdot, \cdots)$ ).

There is highly significant relation between vaccination and the prevalence of hepatitis $B$ 
Irq $\mathrm{J}$ Pharm Vol. ${ }^{9} \& 1 \cdot$, No. ',

$r \cdot 1$.

seropositivity, hepatitis B was positive in

$11 . r 4 \%$ of those patients who were

Table 1: Thalassemic patients with hepatitis B and C.

\begin{tabular}{|c|c|c|c|}
\hline & $\begin{array}{l}\text { Hepatitis B } \\
\text { Number }\end{array}$ & $\begin{array}{l}\text { Hepatitis C } \\
\text { Number }\end{array}$ & Hepatitis B and C Number \\
\hline Age(year) & No. & No. & No. \\
\hline.-0 & $\circ$ & rV & 1 \\
\hline $7-1$. & 1 & $\leqslant v$ & r \\
\hline $11-10$ & $v$ & TV & $\varepsilon$ \\
\hline 17-r. & 0 & r & $\varepsilon$ \\
\hline Total & rt & $17 \varepsilon$ & it \\
\hline \multicolumn{4}{|l|}{ Sex } \\
\hline Male & 11 & 9. & 9 \\
\hline Female & ir & $V \varepsilon$ & r \\
\hline Total & rt & $17 \varepsilon$ & it \\
\hline \multicolumn{4}{|l|}{ Residence } \\
\hline Urban & 1. & vo & $\circ$ \\
\hline Rural & ir & 19 & v \\
\hline Total & rt & $17 \varepsilon$ & it \\
\hline $\begin{array}{l}\text { Family history } \\
\text { positive }\end{array}$ & ir & 94 & 1. \\
\hline $\begin{array}{l}\text { Family history } \\
\text { nagative }\end{array}$ & 1. & (1) & r \\
\hline $\begin{array}{l}\text { Hepatitis B Vaccination status } \\
\text { Positive }\end{array}$ & 1 & & \\
\hline $\begin{array}{l}\text { Negative } \\
\text { Incomplete }\end{array}$ & $\begin{array}{l}\text { IV } \\
\text { iv }\end{array}$ & & \\
\hline Splenectomized patient & $1 \varepsilon$ & $1 . r$ & 9 \\
\hline Non-splenectomized patient & 9 & זי & r \\
\hline $\begin{array}{l}\text { Thalassemia type } \\
\text { Major } \\
\text { Intermediate }\end{array}$ & $\begin{array}{l}r T \\
.\end{array}$ & $\begin{array}{l}17 . \\
\varepsilon\end{array}$ & $\begin{array}{l}{ }^{i r} \\
.\end{array}$ \\
\hline $\begin{array}{l}\text { Transfusion frequency } \\
\text { <ir per }\end{array}$ & 7 & & \\
\hline$>1 r$ per & iv & $\begin{array}{l}\text { or } \\
111\end{array}$ & $\begin{array}{l}r \\
q\end{array}$ \\
\hline $\begin{array}{l}\text { Disease duration } \\
.-0 \text { year } \\
>>\text { year }\end{array}$ & $\begin{array}{l}\text { I } \\
\text { iv }\end{array}$ & $\begin{array}{l}\text { ro } \\
\text { rira }\end{array}$ & 11 \\
\hline
\end{tabular}


not vaccinated while only $\because r v \%$ of thalassaemic patients were completely vaccinated regime $(p<\cdot \ldots \cdot)$.

There is highly significant relation between splenectomy and the prevalence of hepatitis B and C, where or. $v \leqslant \%$ of splenectomized patients had positive hepatitis $(0.9) \%$ with hepatitis $B, \leq r . . r \%$ with hepatitis $\mathrm{C}$ and $r . \wedge \%$ with co-infection) while only $19 .+r \%$ of the non-splenectomized patients were hepatitis positive $(p<\cdot . \cdots)$.

There is highly significant association between the type (severity) of thalassaemia and the seropositivity of hepatitis B and C, where the prevalence of hepatitis was high in thalassaemia major ( $r$ r. 9 r\%) while only $\urcorner. r \circ \%$ in thalassaemia intermedia had hepatitis $(p<\cdot, \cdots)$.

The seropositivity for hepatitis B and C is significantly related to the frequency of blood transfusion per year, where $r . . T v \%$ of the hepatitis positive patients received ir or less transfusion per year ( $r \%$ for hepatitis B $\vee .7 v \%$ for hepatitis $C$ and $1 \%$ for coinfection) while $\leqslant r . r \%$ of the hepatitis positive patients received more than ir transfusion per year $(0 . r) \%$ with hepatitis $B, r \leqslant .0 \%$ with hepatitis $C$ and $r . \vee \vee \%$ for co-infection $(p<\cdot \ldots \cdot)$.

There is highly significant relation between the prevalence of hepatitis $B$ and $C$ and the duration of the disease, where $\leqslant 7 . r 1 \%$ of the patients whom disease duration more than 7 years $(0.1 \%$ with hepatitis $B, r \wedge . .0 \%$ with hepatitis $C$ and $r . r \leqslant \%$ with co-infection) while only $1 \leqslant .7 r \%$ of the patients with the disease less than 7 years $(p<\cdot . \cdots)$ ).

\section{Discussion}

The prevalence of hepatitis $B$ and $C$ was higher in patients older than 10 years in Mosul and also in Taiwan." The residence was not risk factor for hepatitis in Mosul and also in Egyptian $^{\circ}$

Vaccination against hepatitis B was crucial factor that affect the prevalence of Hepatitis and this has been shown previously.' Family history was a significant risk factor ( $p$ value $<. . \cdots 1)$ this has also been shown previously. ${ }^{r, r}, \quad$ The positive relationship between the severity of thalassaemia, the duration of the disease and frequency of transfusion and prevalence of hepatitis $B$ and
C was shown in this study and previous studies. ${ }^{\text {s-1 }}$

In conclusion, seropositivity is significantly related to age, vaccination, family history of hepatitis, history of splenectomy, number of blood transfusion per year; and severity of thalassaemia.

\section{References}

1. Mosley JW. The Epidemiology of Viral Hepatitis. An Overview. Am J Med Sci 19V0:YOr-rV.

r. Vial Hepatitis Reposly of WHO Scientific Group. WHO Technical Report Series $01 Y$. Geneva. World Health Organization. 19vr.

r. John D.S, Larry KP. viral hepatitis. chap. I $V v$, Behrman, Nelson $Y \cdots, P P . \vee \vee \Lambda-$

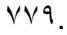

£. Chung JL, Kao JH, Kong MS, Yang CP. Hepatitis $C$ and $G$ virus infections in polytransfused children. Eur. J. Pediatr 199V;107(V):0 $07-9$.

- el-Gohary A, Hassan A, Nooman Z, Lavanchy D,Mayerat C, el-Ayat A, Fawaz N,Gobran F, Ahmed M, Kawano F. High prevalence of hepatitis $\mathrm{C}$ virus among urban and rural population groups in Egypt. Acta Trop 1990;09(r):100-71.

ฯ. Chang $\mathrm{MH}$. Chronic hepatitis virus infection in children. J-Gastroenterol Hepatol 199^; Ir(0):0 $01-\Lambda$.

v. Mangiagli A, Campisi S, Piazza L, LoMonaco D. Horizontal transmission of hepatitis $\mathrm{C}$ virus to family members of infected polytransfused pediatric patients. Pediatr. Med. Chir 1990;1V(r):101-r.

^.Papanastasiou DA, Spiliopouloul, Katinakis S, Karana Ginopoulou A,Repanti M. Lack of transmission of hepatitis $C$ in household contacts of children with homozygous beta-thalassaemia. Acta. Haematol 199v;

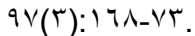

१.Laosombat $\quad \mathrm{V}, \quad$ Pornpatkul M, Wongchanchailert $M$, Worachat $K$, Wiriyasatienku A. The prevalence of hepatitis $C$ virus antibodies in thalassemic patients in the south of Thailand. Southeast Asian J. Trop-Med-Public-

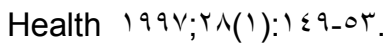

1. Rebulla P. Blood transfusion in beta thalassaemia major. Transfus. Med 1990 $; \circ(\varepsilon)$ : r $\leqslant \vee-01$.

11. Saraswat S, Bangrjee K, Chaudhury $N$, Mahant T. Posttransfusion hepatitis type $B$ following multiple transfusion of $\mathrm{HBs} \mathrm{Ag}$ negative blood. J. Hepatol 1997;r०(०): тrq- $\varepsilon$ r. 
Irq J PharmVol. ${ }^{9} \&$ '·, No. ',

$r \cdot 1$. 